口腔癌患者の唾液中に見いだしたペプチド, デフェンシンに関する研究

\author{
水川展吉
}

\title{
Defensin, a peptide detected in the saliva of patients with oral cancer patients
}

\author{
Nobuyoshi Mizukawa
}

\begin{abstract}
The saliva of patients with oral cancer was subjected to reversed-phase HPLC and a peak (P14) eluted with a linear gradient of acetonitrile. In contrast, minimal P14 was detected in the saliva of healthy volunteers. P14 showed strong absorbance at a $\lambda \max$ of $278 \mathrm{~nm}$, and showed high fluorescence at $\lambda$ em of $304 \mathrm{~nm}$ and $348 \mathrm{~nm}$ with a $\lambda$ ex of $278 \mathrm{~nm}$. It seemed that P14 was a peptide containing tryptophan and tyrosine. The molecular weight of P14 was 3, 442 daltons on a mass spectrometry. Amino acid analysis by Edman degradation and homology studies showed that P14 was consistent with human $\alpha$-defensin 1 (HNP-1), a peptide that belongs to the defensin family. HNP-1 was detected in the whole saliva of cancer patients, but only low levels were found in the serum, the parotid saliva, and the submandibular and sublingual saliva. The concentrations of HNP-1 in the whole saliva of the 8 preoperative and 13 postoperative carcinoma patients were $11.3 \pm 7.8$ and $5.9 \pm 5.6 \mu \mathrm{g}$ $/ \mathrm{ml}$ (mean \pm S. D.), respectively. The concentration in the preoperative patients was higher than that in the postoperative patients and gradually decreased after operation. However, HNP- 1 was found in the saliva of patients even a half year after operation. The origin of HNP- 1 in the saliva of oral cancer patients was not clear, but it was suggested that HNP-1 might act as a defensive substance against carcinoma.
\end{abstract}

Key words: saliva (唯液), oral cancer (口腔癌), reversed-phase HPLC (逆相高速液体クロマトグ ラフィー), defensin (デフェンシン), HNP-1（ヒト型デフェンシン 1)

緒 言

唾液は口腔内の潤滑作用や口腔粘膜の保護作用，唾 液中の殺菌性蛋白質や $\operatorname{IgA}$ などによる抗微生物作用 および酵素による消化作用など種々の生理作用によっ てロ腔内環境を維持する重要な働きをしていると考え られている ${ }^{1)}$. 現在までヒト喠液中には40種類以上の 蛋白質やペプチドが分泌されていることが報告されて いる ${ }^{2)}$ ，それに加え唾液中には歯肉溝浸出液由来と思

岡山大学歯学部口腔外科学第一講座

（主任 : 菅原利夫教授）

Department of Oral and Maxillofacial Surgery 1, Okayama University Dental School (Chief: Prof. Toshio Sugahara)

受付日：平成10年 1 月 22 日
われる抗菌物質ミエロペルオキシダーゼなど唾液腺以 外から分泌されるぺプチドも混在している3).

唾液中のそのような成分が全身疾患や口腔疾患時に その分泌成分の質や量に変動がおこることが示唆され ており ${ }^{4)}$ ，これらの成分を簡便に測定してその変動と 疾患との関連性を明らかにすることは疾患の早期発見 や予後診断，治療に役立つものと考えられるが，この 領域における研究は非常に少ない.

本研究は逆相高速液体クロマトグラフィー（HPLC） を用いてヒト唾液を試料とし，塩基性の低分子ペプチ ドを分析中に偶然に口腔癌患者唾液中に特異的に出現 するピーク（P14）を見いだしたことから ${ }^{5)}$ ，この成 分を同定し癌疾患との関連性を追及する目的で行った。 精製したP14成分の光学的性質, 分子量およびアミノ

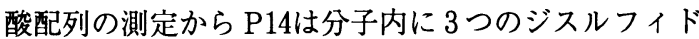


結合をもつ塩基性の低分子ペプチドで, 現在デフェン シンファミリーとして分類されているデフェンシン 1 （HNP-1）に一致するものであった. デフェンシン は好中球や小腸上皮組織などに見いだされたぺプチ ド6,7) で細菌, 真菌, ウイルスなどに対する広範囲な 抗微生物作用および抗腫瘍作用など多彩な生物活性を もち生態防御物質として近年注目されている ${ }^{8)}$. 本研 究では口腔癌患者の全唾液から P14成分を分離, 精製 し，その構造を決定し，更に簡便な定量法を考案して 癌患者の唾液内 HNP-1 の変動から病態的役割につい て考察した.

\section{材料および方法}

\section{1. 被験者}

岡山大学歯学部附属病院第一口腔外科に来院した口 腔扁平上皮癌 $(\mathrm{CA})$ 患者 16 名 (年齢41 79, 男性 6 名, 女性10名)の協力を得た（Table 1). 術前の被験者唾 液 (手術前 1 週間以内) は抗癌剂治療および放射線治 療を受けていないものを用いた。 また術後の被験者唾 液は, 観血的治療により肉眼的ならびに X 線学的に腫 瘍の存在を認めないものを用いた。

\section{2 . 唾液の採取と調整}

被験者の混合唾液は手術の前後においてクエン酸刺 激によるスピッティング法によって採取した，耳下腺 唾液は久保木 $\left.{ }^{9}\right)$ らの方法で採取し, 顎舌下腺唾液は岸 本10)らの方法によって得た。採取した喠液は，ただち にクエン酸で PH $3.0 に$ 調整し, $-20^{\circ} \mathrm{C}$ 以下に保存して 試料に供した. 対照として口腔疾患のない健常者 (年 齢23 78, 男性14名, 女性 4 名) からクエン酸刺激で得 た混合唾液を用いた。

\section{3. 血清}

ヘパリンを添加した患者血液から血清を分離し, ク エン酸で $\mathrm{pH} 3.0$ に調整して $-20^{\circ} \mathrm{C}$ に保存した.

\section{4. 唾液および血清中のペプチド（HNP-1）の} 測定

唾液および血清試料は室温で融解し，遠心分離 $(15,000 \mathrm{rpm} / 5$ 分間）して上清液を得た。その $10 \mu \mathrm{l}$ について逆相高速液体クロマトグラフィー（HPLC） で分析した. HPLC は C18-AM カラム $(4.6 \times 250 \mathrm{~mm}$, nacalai tesque, Japan）および送液ポンプ（島津製 作所・LC-10AS）を用い, A 液：0.05\%トリフルオロ 酢酸（TFA）を含む10\%アセトニトリル，B 液：0.05 \% TFA を含む50\%アセトニトリルの A 液から B 液に おける20分間の直線濃度勾配法 (流速, $1 \mathrm{ml} / \mathrm{min}$ ) によって行った. HNP-1の定量は, 合成 HNP-1（ペ プチド研究所，Japan）を用いて HPLCのクロマトグ ラムにおけるピーク高から検量線を作り，唾液および 血清中の HNP- 1 量を測定した.

\section{HNP-1 の分離, 精製}

唾液からの HNP-1の分離には, セミ分取用カラム (C18-AM, 7.6×250mm, nacalai tesque, Japan) を 使用して分析におけるのと同じ溶離液の $\mathrm{A}$ 液と $\mathrm{B}$ 液を 用いて 20 分間の直線濃度勾配法 (流速, $2.3 \mathrm{ml} / \mathrm{min}$ ) によって HPLCを行いHNP-1を分取した.この分画 をさらに同じ条件下に再 HPLC を行い HNP- 1 を精 製した. 精製した HNP-1 は濃縮後, 凍結乾燥し保存 した.

\section{HNP- 1 の光学的性質}

HNP- 1 を A 液に溶解し分光光度計 (UV-180, 島津 製作所, Japan）で紫外部吸収スペクトルを測定した。 蛍光スペクトルは分光蛍光光度計 (RF-500, 島津製作 所）を用いて励起波長 $278 \mathrm{~nm}$ における蛍光を測定した.

\section{7. 分子量の測定}

トリプルステージ四重極型 TSQ700 (Finnigan MA 社 U.S.A.）を用いエレクトロスプレー質量分析法に よって測定した.

\section{8. アミノ酸配列の測定}

プロテインシーケンサー (Applied Biosystems 社, U.S.A.) を用いて気相エドマン法によってアミノ酸 配列を測定した. またシステインの測定は試料をトリn-ブチルホスフィンと 4 -ビニルピリジンを用いて還 元 s-ピリジルエチル化した後プロテインシーケンサー によって行った ${ }^{11)}$.

\section{9.ホモロジー検索}

蛋白質のアミノ酸配列のホモロジー検索はSWISSPROT データベースを用いて行った。

\section{0. 統計学的検討}

実験結果の数値は, 平均值士標準偏差 (S.D.) で示 L, CA 患者（術前と術後の癌患者）と健常者の唾液 中の HNP- 1 濃度の有意差の検定は Welch の検定 (両側検定), 術前と術後の癌患者唾液中の HNP- 1 濃 度の有意差の検定は, Student の paired $\mathrm{t}$ 検定（片側 検定）を用いて行った.

\section{TNM 分類}

TNM 分類は, 1987年 UICC 分類 ${ }^{12)}$ に従った.

\section{結}

\section{果}

\section{1. 唾液の HPLC}

1 ) 健常者と CA 患者唾液の比較

Fig. 1 は, 代表的な手術前の CA 患者の混合唾液お よび対照として健常者の唾液についての HPLC のク ロマトグラムを示す. CA 患者唾液には，保持時間約 14分後に顕著なピーク（P14）が認められたが（Fig. 1, CA, 矢印), 健常者の唾液には, P14は非常に微小かほ とんど認められなかった。

2 ) 耳下腺および䫟舌下腺唾液の HPLC

$\mathrm{CA}$ 患者唾液中に見られる $\mathrm{P} 14$ が耳下腺あるいは顎 
$\mathrm{H}$

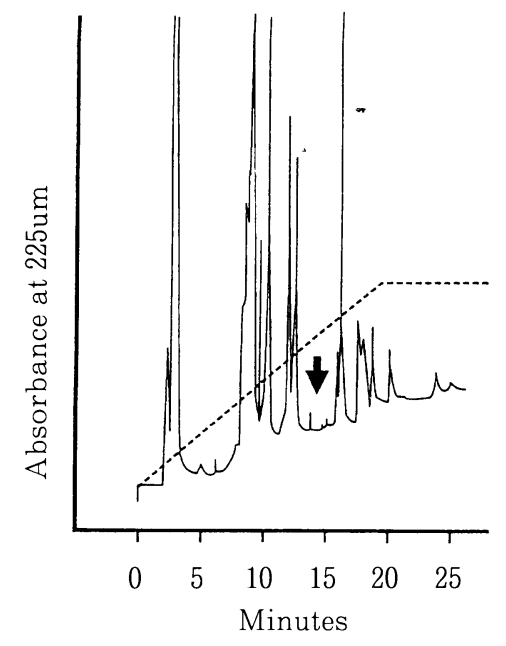

$\mathrm{CA}$

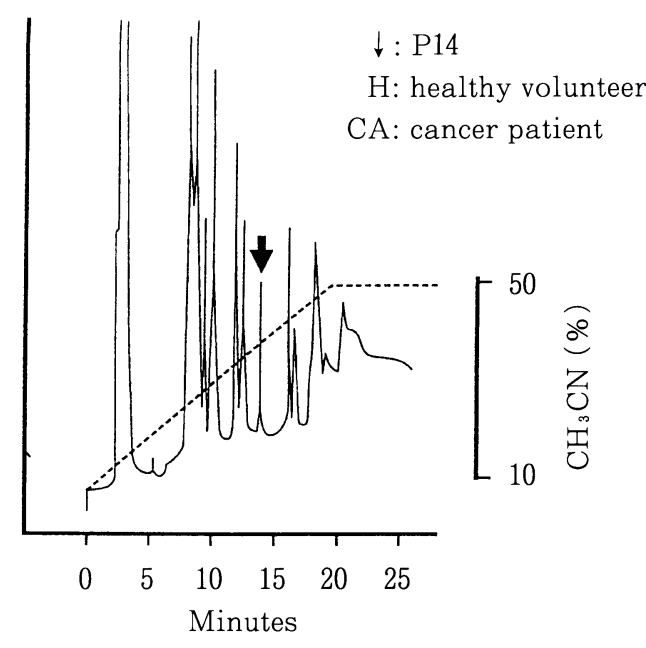

Fig. 1 Reversed-phase HPLC of the whole saliva of a healthy volunteer and a patient with oral carcinoma

Ten microliters of the saliva sample was applied on a column $\left(\mathrm{C}_{18} \mathrm{AM}\right)$ and a linear gradient of $10-50 \%$ acetonitrile in $0.05 \%$ trifluoroacetic acid was carried out for $20 \mathrm{~min}$. The flow rate was $1.0 \mathrm{ml} / \mathrm{min}$. A unique peak (P14, arrow) was detected in the saliva of a cancer patient after about $14 \mathrm{~min}$, and P14 was little detected in the saliva of a healthy volunteer. The broken line indicates the gradient concentration of acetonitrile.

$\downarrow:$ P14 $\quad 1$ : parotid saliva

2 : submandibular and sublingual saliva 3 : whole saliva

1

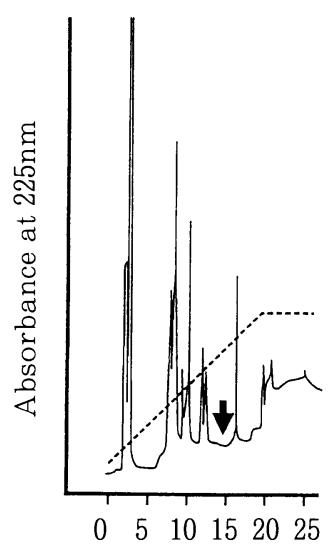

2

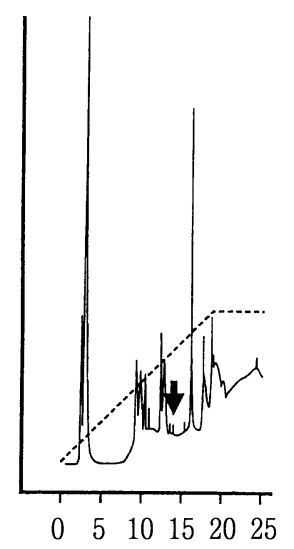

3

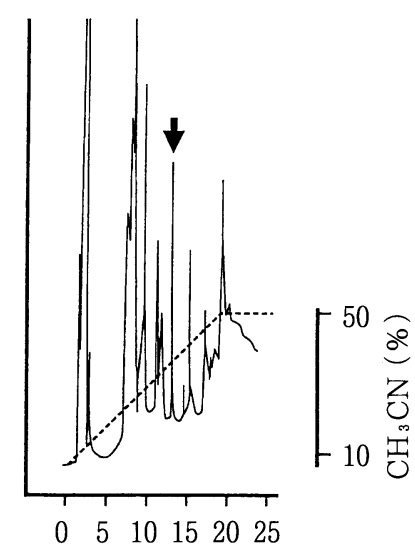

Fig. 2 HPLC of the parotid saliva, submandibular and sublingual gland saliva and whole saliva of an oral carcinoma patient

P14 was detected in the whole saliva of a patient, but was minimal in the parotid saliva and the submandibular and sublingual saliva. 
A

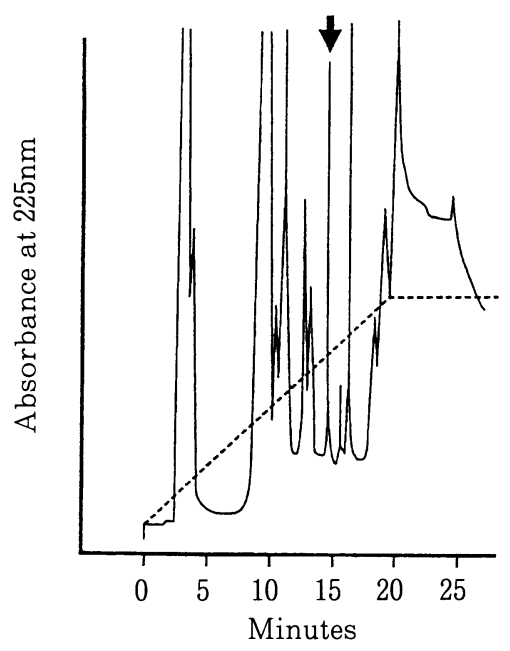

B

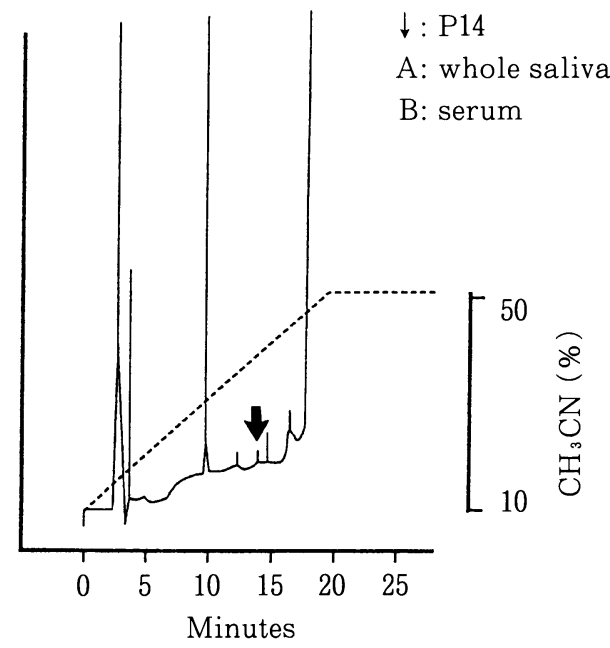

Fig. 3 HPLC of the whole saliva and the serum of a patient with oral carcinoma P14 was detected in the whole saliva of a patient, but was minimal in the serum.

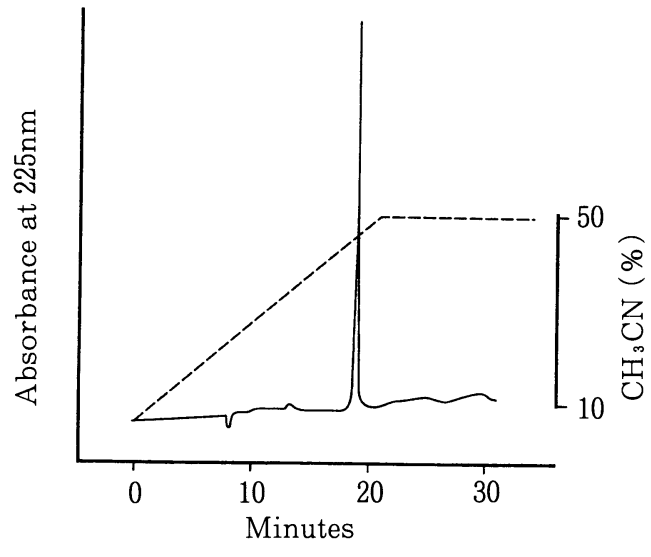

Fig. 4 HPLC of purified P14

P14 was rechromatographed on a $\mathrm{C}_{18} \mathrm{AM}$ column $(7.6 \times 250 \mathrm{~mm})$ in a linear gradient $10-50 \%$ acetonitrile in $0.05 \%$ trifluoroacetic acid. The flow rate was $2.3 \mathrm{ml} / \mathrm{min}$.

舌下腺からの分泌成分に由来するものかどうかを検討 した. Fig. 2 は, 術後13か月の同一人の耳下腺, 䪽舌 下腺および混合唾液について HPLC の結果を示す。 P14は混合唾液中には顕著に認められたが, 耳下腺と 顎舌下腺唾液中には微小にしか認められなかった。

\section{2. 血清中の $\mathrm{P} 14$}

$\mathrm{CA}$ 患者の唾液中に見い出された $\mathrm{P} 14$ 成分について 患者血清中にも存在するのかどうかを検索した. 測定 した 4 例において，唾液中の P14は顕著に認められた が，血清中にはほとんど $\mathrm{P} 14$ は認められなかった． Fig. 3 は, その内の 1 例で, 唾液中には高濃度の P14 が, 存在したが, 血清中には測定できなかった.

\section{P14成分の同定}

1 ) P14の光学的性質

CA 患者から分離, 精製したP14は HPLCにおいて 単一のピークを示した (Fig. 4 ). この P14について光 学的性質を検討した. Fig. 5 にP14の紫外部吸収およ び蛍光スペクトルを示す. P14は波長 $278 \mathrm{~nm}$ において 吸収極大を示したので蛋白質であることが予想された。 また励起波長 $278 \mathrm{~nm}$ における蛍光は波長 $304 \mathrm{~nm}$ と 348 $\mathrm{nm}$ に極大を示す 2 相性のスペクトルを示し, 前者は チロシン, 後者はトリプトファンのそれに一致してい た.

\section{2 ) P14の分子量}

3 名の CA 患者からそれぞれ精製したP14について 質量分析法によって分子量を測定した。その結果， P14の分子量はそれぞれ3442.8，3443.6，および3439.0 daltons で平均分子。量は $3,441.8$ daltons であった. Fig. 6 に代表的な P14のマススペクトルを示した.

3 ) P14のアミノ酸配列の測定

気相プロテインシーケンサーによって直接的に P14 のアミノ酸配列を測定した結果, $\mathrm{N}$ 末端から測定可能 なアミノ酸残基は $\mathrm{A}-\mathrm{Y}-\mathrm{RIPA}$ - IAGERRYGT - 
A

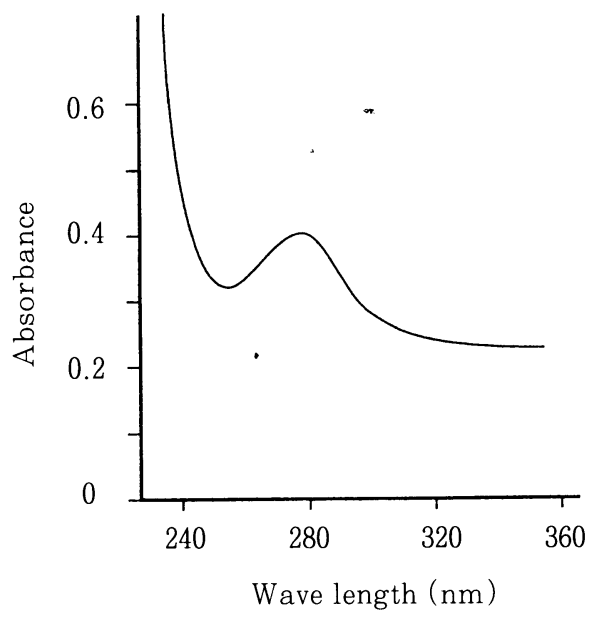

B

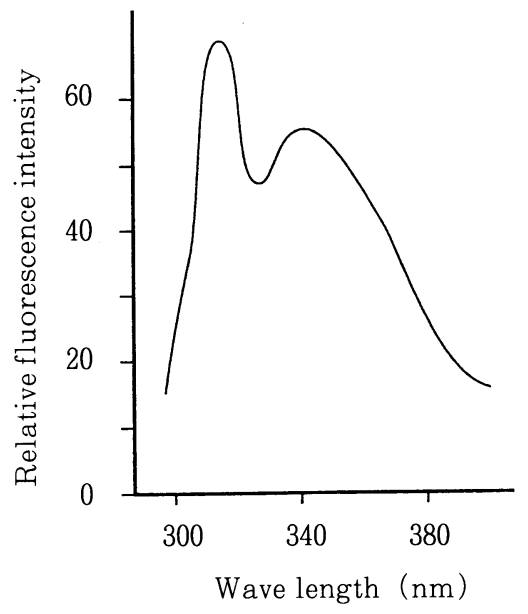

Fig. 5 Ultraviolet absorption and fluorescence spectra of P14 A: absorption curve of P14 B: fluorescence spectrum ( $\lambda$ ex, 278nm)

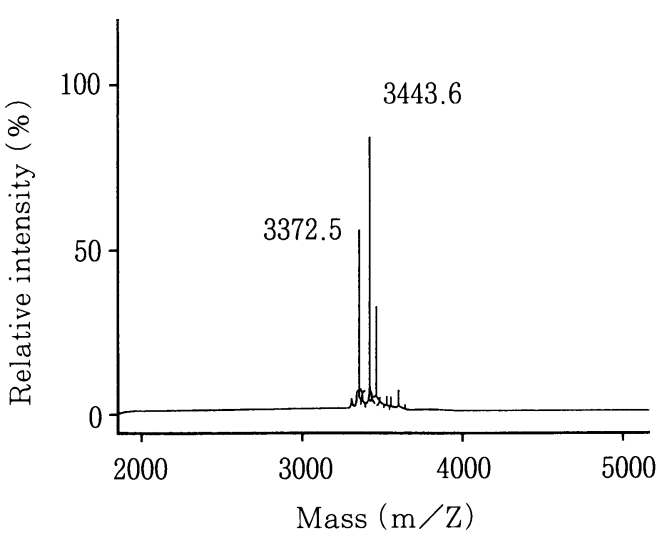

Fig. 6 Mass spectrum of P14

IYQGRLWAFーーであった。このアミノ酸配列は 3 名の患者からえたP14についてすべて同一の配列であっ た.アミノ酸配列のホモロジー検索から，89\%のホモ ロジーに拈いてヒト型デフェンシン 1 (HNP-1) の それと一致していた. 次いで P14を還元 S-ピリジルエ チル化した後シーケンサーで測定した結果, 未決定ア ミノ酸残基はすべてシステインであった. P14の分子 内の $3 つ$ づスルフィド結合を考慮した分子量の計算 值は3,442.1 daltons となりこの值はほほ実測值と一 致していた.

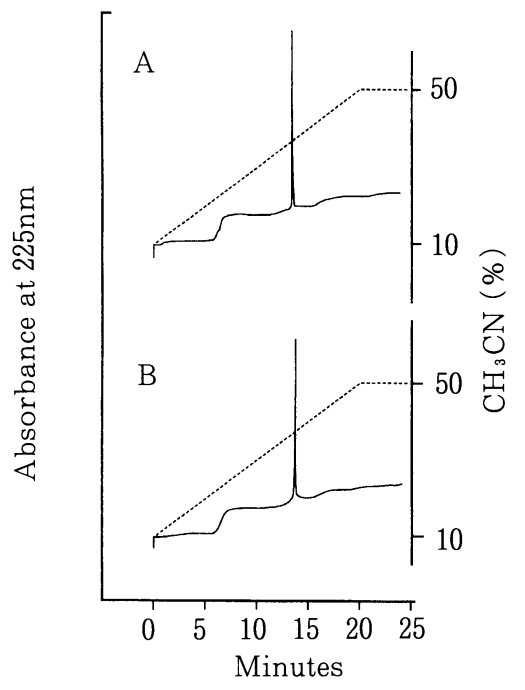

Fig. 7 HPLC of synthesized human defensin 1 (HNP-1) and purified P14

A: synthesized HNP-1 $\quad$ B: purified P14

4 ) 合成 HNP- 1 と P14の HPLC

Fig. 7 は合成 HNP- 1 と唾液 P14の HPLC におけ るクロマトグラムを示す. 両者の保持時間は 14.4 分で 完全に一致していた. 以上の結果は P14が HNP-1 1 と 同一のペプチドであることを示すものである.Fig. 8 にヒト型デフェンシン 1（HNP-1）の構造式を示し 


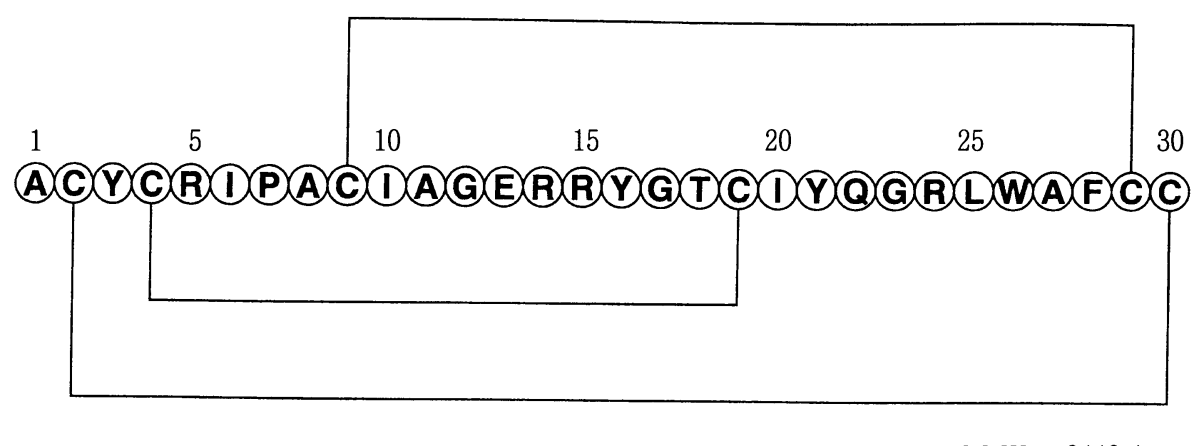

M.W. $=3442.1$

Fig. 8 Structure of human defensin 1 (HNP-1)

A: alanine, C: cysteine, E: glutamic acid, F: phenylalanine, G: glycine, I: isoleucine, $\mathrm{L}$ : leucine, $\mathrm{P}$ : proline, $\mathrm{Q}$ : glutamine, $\mathrm{R}$ : arginine, $\mathrm{T}$ : threonine, $\mathrm{Y}$ : tyrosine, $\mathrm{W}$ : tryptophan

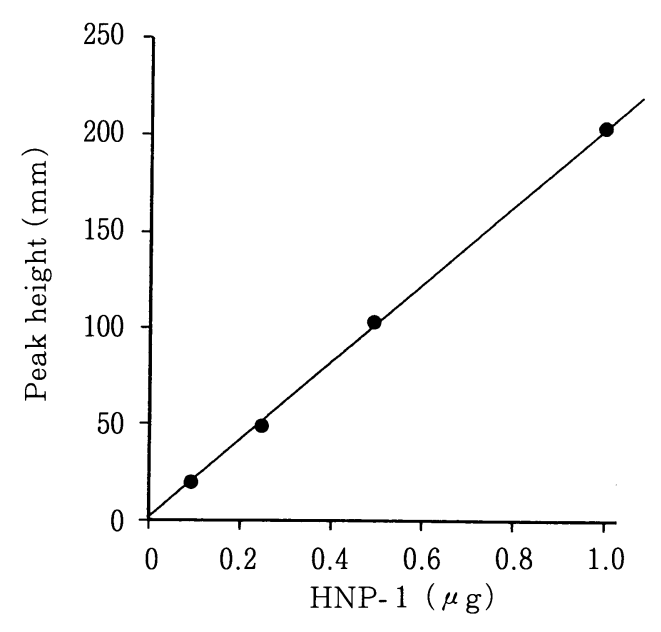

Fig. 9 Calibration curve for HNP-1

た ${ }^{13)}$.

\section{4. 唾液中の HNP- 1 の定量}

1 ) 定量法の検討

合成 HNP- 1 の0.1 $1 \mu \mathrm{g} / 10 \mu \mathrm{l}$ の濃度において HPLCを行いそれぞれのピーク高から検量線を作っ た. Fig. 9 に示すように0.1 $1 \mu \mathrm{g}$ の濃度範囲で HNP-1のピーク高には直線関係が認められた。次に 健常者の唾液に既知濃度の合成 HNP-1 を加え， HPLCによる回収率と変動係数 (C.V.) を測定した (Table 2 ). その結果, 10 および $25 \mu \mathrm{g} / \mathrm{ml}$ において添 加したHNP-1の回収率はそれぞれ89および $98 \%$ を示 し, それらのC.V. 值は $3 \%$ 以下であった.
2 ) 健常者および CA 患者唾液中の HNP-1

Table 1 に健常者と CA 患者唾液中の HNP-1 の濃 度を示す. 健常者唾液中の HNP- 1 濃度は測定した 18 名のいずれも $1.5 \mu \mathrm{g} / \mathrm{ml}$ 以下であった。一方 CA 患 者群において術前患者群は健常者群に比較して有意に 高い濃度を示し（P<0.01），また術後患者群において も健常者群に比較して有意に高い濃度を示した $(\mathrm{P}<0.01)$. また同一患者 5 人の術前, 術後の HNP- 1 濃度はそれぞれ9.3 $\pm 5.1,4.6 \pm 4.7 \mu \mathrm{g} / \mathrm{ml}$ (Mean \pm S. D.) で術前の方が術後に比較して有意に高い濃度 を示した $(\mathrm{P}<0.005)$. 癌発症部位との関連性は見られ なかった.また唾液内 HNP-1 濃度は, 術後日数の経 過とともに減弱する傾向を示した（Fig. 10). しかし 術後 3 年 2 か月経過観察中で, 肉眼的およびX 線的に 再発の症状のない患者において唾液中 HNP- 1 が健常 者のレベル以上に存在するのが認められた（Table 1 ).

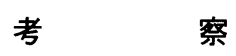

CA 患者の混合唾液中に HPLCによって見いだし た特異なピーク (P14) は光学的性質からトリプトファ ンとチロシンを含むぺプチド成分であることが推測さ れた．質量分析によってこの P14の分子量は 3,442 daltons であり， $\mathrm{N}$ 末端からのアミノ酸配列の解析， および合成ぺプチドとの比較において P14がヒト型デ フェンシン13)に属するペプチドであることが確定で きた.この $\mathrm{P} 14$ は $\mathrm{CA}$ 患者の術前および術後の唾液中 に顕著に出現するが, 健常者の唾液中には微量にしか 存在せず, HPLC ではほとんど認めることができなかっ た. 現在までヒト全唾液中のデフェンシンの存在に関 する報告はない． 
Table 1 CONCENTRATION OF HNP- 1 IN THE SALIVA OF ORAL CANCER PATIENTS

\begin{tabular}{|c|c|c|c|c|c|}
\hline & Age (Sex) & TNM & Site & $\mathrm{HNP}-1(\mu \mathrm{g} / \mathrm{ml})$ & Follow up \\
\hline $\mathrm{H}(\mathrm{n}=18)$ & $\stackrel{23-78}{-}$ & - & - & $\begin{array}{c}0.8 \pm 0.6 \\
(\text { Mean } \pm \text { S.D. })\end{array}$ & - \\
\hline $\begin{array}{l}\text { Pre-Op (SCC) } \\
1 \star \\
2 \star \star \\
3 \star \star \star \\
4 \star \star \star \star \\
5 \star \star \star \star \star \\
6 \\
7 \\
8\end{array}$ & $\begin{array}{l}41(\mathrm{M}) \\
75(\mathrm{~F}) \\
41(\mathrm{M}) \\
65(\mathrm{~F}) \\
64(\mathrm{~F}) \\
53(\mathrm{~F}) \\
64(\mathrm{~F}) \\
56(\mathrm{M})\end{array}$ & $\begin{array}{l}\mathrm{T}_{4} \mathrm{~N}_{0} \mathrm{M}_{0} \\
\mathrm{~T}_{2} \mathrm{~N}_{0} \mathrm{M}_{0} \\
\mathrm{~T}_{2} \mathrm{~N}_{0} \mathrm{M}_{0} \\
\mathrm{~T}_{2} \mathrm{~N}_{0} \mathrm{M}_{0} \\
\mathrm{~T}_{1} \mathrm{~N}_{0} \mathrm{M}_{0} \\
\mathrm{~T}_{4} \mathrm{~N}_{\mathrm{X}} \mathrm{M}_{\mathrm{X}} \\
\mathrm{T}_{4} \mathrm{~N}_{2} \mathrm{M}_{\mathrm{b}} \\
\mathrm{T}_{1} \mathrm{~N}_{0} \mathrm{M}_{0}\end{array}$ & $\begin{array}{c}\text { UG } \\
\text { UG } \\
\text { T } \\
\text { UG } \\
\text { T } \\
\text { UG } \\
\text { ULG } \\
\text { MF }\end{array}$ & $\begin{array}{c}17.2 \\
9.8 \\
2.9 \\
11.8 \\
4.9 \\
17.2 \\
25.5 \\
1.0 \\
11.3 \pm 7.8 \\
\text { (Mean士S.D.) }\end{array}$ & $\begin{array}{l}- \\
- \\
- \\
- \\
- \\
- \\
- \\
-\end{array}$ \\
\hline $\begin{array}{c}\text { Post-Op (SCC) } \\
1 \star \\
2 \star \star \\
3 \star \star \star \\
4 \star \star \star \star \\
5 \star \star \star \star \star \\
6 \\
7 \\
8 \\
9 \\
10 \\
11 \\
12 \\
13\end{array}$ & $\begin{array}{l}41(\mathrm{M}) \\
75(\mathrm{~F}) \\
41(\mathrm{M}) \\
65(\mathrm{~F}) \\
64(\mathrm{~F}) \\
68(\mathrm{~F}) \\
52(\mathrm{~F}) \\
43(\mathrm{M}) \\
69(\mathrm{~F}) \\
79(\mathrm{M}) \\
64(\mathrm{~F}) \\
75(\mathrm{~F}) \\
70(\mathrm{M})\end{array}$ & $\begin{array}{l}\mathrm{T}_{4} \mathrm{~N}_{0} \mathrm{M}_{0} \\
\mathrm{~T}_{2} \mathrm{~N}_{0} \mathrm{M}_{0} \\
\mathrm{~T}_{2} \mathrm{~N}_{0} \mathrm{M}_{0} \\
\mathrm{~T}_{2} \mathrm{~N}_{0} \mathrm{M}_{0} \\
\mathrm{~T}_{1} \mathrm{~N}_{0} \mathrm{M}_{0} \\
\mathrm{~T}_{1} \mathrm{~N}_{0} \mathrm{M}_{0} \\
\mathrm{~T}_{1} \mathrm{~N}_{0} \mathrm{M}_{0} \\
\mathrm{~T}_{2} \mathrm{~N}_{0} \mathrm{M}_{0} \\
\mathrm{~T}_{2} \mathrm{~N}_{1} \mathrm{M}_{0} \\
\mathrm{~T}_{2} \mathrm{~N}_{0} \mathrm{M}_{0} \\
\mathrm{~T}_{1} \mathrm{~N}_{0} \mathrm{M}_{0} \\
\mathrm{~T}_{4} \mathrm{~N}_{0} \mathrm{M}_{0} \\
\mathrm{~T}_{2} \mathrm{~N}_{0} \mathrm{M}_{0}\end{array}$ & $\begin{array}{c}\text { UG } \\
\text { UG } \\
\text { T } \\
\text { UG } \\
\text { T } \\
\text { T } \\
\text { T } \\
\text { T } \\
\text { ULG } \\
\text { T } \\
\text { LG } \\
\text { UG } \\
\text { MF }\end{array}$ & $\begin{array}{r}13.7 \\
2.9 \\
1.0 \\
1.5 \\
4.0 \\
18.6 \\
3.2 \\
2.5 \\
6.4 \\
0.0 \\
2.9 \\
6.4 \\
14.2 \\
5.9 \pm 5.6 \\
\text { (Mean } \pm \text { S.D.) }\end{array}$ & $\begin{array}{r}6 \mathrm{M} \\
6 \mathrm{M} \\
8 \mathrm{M} \\
5 \mathrm{M} \\
4 \mathrm{M} \\
8 \mathrm{M} \\
11 \mathrm{M} \\
1 \mathrm{Y} 9 \mathrm{M} \\
1 \mathrm{Y} 9 \mathrm{M} \\
1 \mathrm{Y} 10 \mathrm{M} \\
2 \mathrm{Y} 8 \mathrm{M} \\
2 \mathrm{Y} 11 \mathrm{M} \\
3 \mathrm{Y} 2 \mathrm{M}\end{array}$ \\
\hline
\end{tabular}

$\mathrm{H}$ : healthy volunteer, SCC: squamous cell carcinoma, UG: upper gingiva, LG: lower gingiva, ULG: upper and lower gingiva, T: tongue, MF: mouth floor.

S.D.: standard deviation, M: month, Y: year, $\star, \star \star, \star \star \star, \star \star \star \star, \star \star \star \star \star$ : same patient

Table 2 RECOVERY OF HNP- 1 ADDED TO HUMAN WHOLE SALIVE

\begin{tabular}{ccc}
\hline $\begin{array}{c}\text { HNP- 1 } \\
(\mu \mathrm{g} / \mathrm{ml})\end{array}$ & $\begin{array}{c}\text { Recovery (\%) } \\
(\text { mean } \pm \text { S.D., } \mathrm{n}=4)\end{array}$ & $\begin{array}{c}\text { C.V. } \\
(\%)\end{array}$ \\
\hline 10 & $88.8 \pm 2.5$ & 2.9 \\
\hline 25 & $98.7 \pm 1.6$ & 1.6 \\
\hline
\end{tabular}

デフェンシンはデフェンシンファミリーとして分類 されているアミノ酸 $29 \sim 34$ 残基からなる一群のペプチ ドでアルギニンを多く含む塩基性のペプチドである. その分子内には 3 つの $\mathrm{S}-\mathrm{S}$ 結合を作る 6 個のシステ
イン残基をもつ共通の基本構造があり，この基本構造 は種を超えた進化の過程でよく保存されていると考え られている ${ }^{8)}$. 最近, この分子内 $S-S$ 結合の位置の 相異から立体構造の違うデフェンシン（ $\beta$-デフェン シン) が見いだされたので, 従来のものを $\alpha$ 型として 区別している14 17). デフェンシンは最初ウサギの肺 胞マクロファージにおいて見いだされ18), その後ヒト 6)，ラット 19)，モルモット ${ }^{20)}$ およびウサギ ${ }^{21)}$ の好中球 で証明された。好中球においては細胞内アズール顆粒 中に眝蔵されている22). またマウスおよびヒトの小腸 粘膜の Paneth 細胞の顆粒内にも存在が認められてい $3^{7,23,24)}$. しかしウサギ以外のマクロファージ, 単球, 好酸球およびリンパ球にはデフェンシンは証明されて 


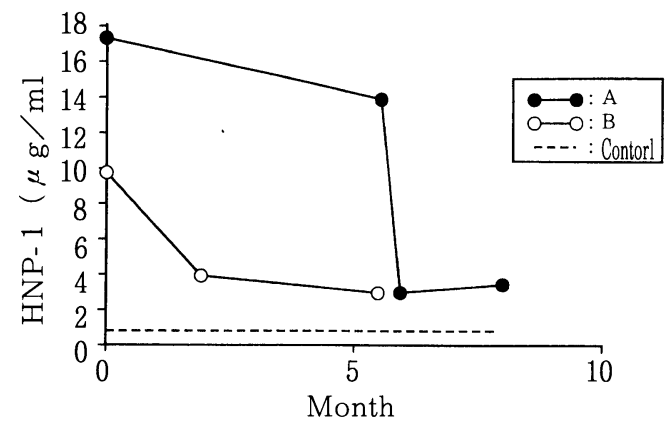

A: patient A B: patient B

Fig. 10 Time course of the concentration of HNP- 1 in the saliva of postoperative patients The concentration of HNP- 1 in the saliva of carcinoma patients decreased after operation. However, the concentration in the saliva of the cancer patients after operation much higher than that in the control saliva.

\section{いない25, 26).}

デフェンシンの生物活性としては細菌 ${ }^{13)}$, 真菌 ${ }^{27)}$,

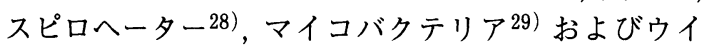
ルス ${ }^{30)}$ に対する殺菌的作用がよく知られており, 癌細 胞などの腫瘍細胞や上皮細胞, 内皮細胞に対しても強 い細胞障害作用がある ${ }^{31,32)}$. また肥満細胞からのヒス 夕ミン遊離活性 ${ }^{33)}$ や単球走化作用 ${ }^{34)}$ および抗 ACTH

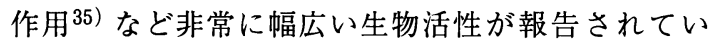
$3^{36)}$.

好中球におけるヒト $\alpha$ 型デフェンシンは HNP- 1 4 の 4 種類 $\left.{ }^{8}\right)$ と腸管上皮からの HD- 5 およびー $6^{7,23,24)}$ の 2 種類の存在が確認されており, ヒト白血 病細胞株 HL-60を用いてデフェンシン遺伝子（def 遺 伝子）の全構造も決定されている37). その塩基配列の 解析からデフェンシンはアミノ酸 93 ～95残基の前躯体 から蛋白分解酵素によってプロセシングを受け最終的 にアミノ酸 29 34残基のデフェンシンになると考えら れている ${ }^{38)}$. ヒト好中球においてはその骨髄芽球の def 遺伝子はわずかにしか発現していないが, 前骨䯣 球および骨髄球では顕著に発現しており, 成熟好中球 ではほとんど発現が認められなくなる。したがって， デフェンシンは未分化な好中球によって合成された後 にアズール顆粒に貯蔵されるものと考えられてい $ろ^{22)}$. アズール顆粒内では HNP- 1 が最も多く存在し, HNP- 3 および 4 は微量にしか存在しない. HNP- 2 は HNP-1の $\mathrm{N}$ 末端のアラニン 1 残基のみを欠く構造で あるので HNP-1 から二次的に生成されるものと考え られる. 実際 HNP- 1 と-3をコードする def 遺伝子の 存在は証明されているが, HNP- 2 の遺伝子は確認さ
れていない8).これらデフェンシンは白血球のアズー ル顆粒のタンパク質の 30 ～50\%を占め，また白血球総 蛋白の $5 \sim 7 \%$ 占めている ${ }^{8)}$.

本研究において CA 患者唾液中に見いだした P14は ヒト型HNP-1であると同定できたが，P14分画のマ ススペクトルにおいて HNP- 2 の質量数に相当するシ グナルも認められるので, P14には微量の HNP-2 が 含まれていることが考えられる。しかし逆相 HPLC において種々の条件下で分析したがP14は単一のピー クを示した（Fig. 4). したがって HPLCを用いてピー ク高を指標とし，合成 HNP-1 の検量線から可及的， 迅速に喠液中の HNP- 1 を定量する方法を考案した。 この方法において唾液に添加した HNP-1の回収率は $89 \sim 98 \%$ で C. V. 值は $3 \%$ 以下の低い值を示し, 唾液 中の HNP - 1 の濃度 $0.1 \sim 1.0 \mu \mathrm{g} / 10 \mu \mathrm{l}$ の範囲内で定 量することができた. デフェンシンの定量法としては 最近 radioimmunoassay（RIA）が開発され高感度で 測定が可能となったが39)，この方法はデフェンシン類 の構造類似性から個々のデフェンシンを分別して測定 することができない.これに対して HPLCを用いる 本研究の方法は HNP-2 の混在は避けられないが HNP- 1 を唾液中の他の成分と分別して定量すること ができ, 唾液試料も $10 \mu \mathrm{l}$ を要するのみで短時間に測 定ができた.

$\mathrm{CA}$ 患者の術前, 術後の唾液中にはヒト好中球に存 在する $\alpha$ 型デフェンシンのみで現在まで $\beta$ 型デフェン シンを確認することはできなかった。また HNP-1 1 は CA 患者の混合唾液には非常に顕著に見られたが, 耳 下腺唾液中にはほとんど認められず, 顎舌下腺唾液に おいては微量にしか認められなかった（Fig. 2)。 こ のことは CA 患者唾液中のデフェンシンがこれら大喠 液腺からの分泌成分ではないことを示唆するもので, おそらく CA 患者唾液中のデフェンシンは口腔内の白 血球 ${ }^{40)}$ に由来するものか, 他の小唾液腺からの分泌, または口腔粘膜や舌上皮細胞から分泌される可能性が 考えられる. CA 患者以外にも口腔内の炎症時の唾液 中にHNP-1が認められるが, この場合には炎症の治 癒とともに完全に消失した（第52回日本口腔科学会総 会, 愛媛, 1998発表). Shiomi ら ${ }^{39)}$ によるRIA 法を用 いたヒト血清中のデフェンシンの濃度は健常者におい ては約 $0.04 \mu \mathrm{g} / \mathrm{ml}$ であり, 同じ方法で Panyutich ら ${ }^{41)}$ は急性檤膜炎や敗血症患者の血清デフェンシン 濃度が $0.12 \mu \mathrm{g}$ から $170 \mu \mathrm{g} / \mathrm{ml}$ の範囲にまで増大す ることを報告している。本研究においては CA 患者の 唾液内 HNP- 1 濃度が $25.2 \mu \mathrm{g} / \mathrm{ml}$ においてさえその 血清中の HNP- 1 を確認することはできなかった。 そ れゆえ，垂液中の HNP-1 が血清に由来しているとは 考え難い. Schonwetter ら ${ }^{16)}$ は，ウシの血清および好 中球に $\beta$ 型デフェンシンが存在することを証明し，さ らにウシの舌上皮組織においても $\beta$ 型デフェンシンが 
存在し, 舌の炎症時に增大すると報告している，ヒト において口腔内 $\mathrm{CA}$ 患者の唾液中にデフェンシンが増 大するのは癌発症時において何らかの刺激が舌上皮組 織に $\alpha$ 型デフェンシンの発現機構を誘導する可能性も 考えられるが,このことに関する実験的な裏付けはな い. 興味あることは CA 患者の術後半年以上経過し再 発の症状もない患者唾液中にも術前よりは低いがデフェ ンシンが顕著に認められることである.デフェンシン には抗腫瘍作用 31,32 があることから癌再発の防御機 構に何らかの役割を演じているものと考えられる. $\mathrm{CA}$ 患者唾液中のデフェンシンが癌発症のどのような 時期に出現するのか, その由来や発現機構を明らかに することは癌再発との関連性や早期診断への指針を得 ることに役立つものと考えられる。

\section{結語}

逆相 HPLC によって口腔癌患者の唾液中に出現す るピーク（P14）を見いだし，以下の結果を得た。

1.P14は, その光学的性質からペプチド様成分であ ることが, 推測され, 質量分析, 分子量の測定および アミノ酸配列の解析とホモロジー検索の結果から合成

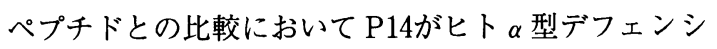
ン 1 (HNP-1) であることを確認した.

2. 混合唾液中の HNP-1 は HPLCを用いて迅速, 簡便に定量できた。

3. 口腔癌患者の混合唾液中に HNP- 1 が認められ たが, 耳下腺唾液, 顎舌下腺唾液, および血清中には ほとんど認められなかった。

4. 口腔癌患者の手術前および術後の唾液中の HNP- 1 の濃度は術前の方が術後より高い傾向を示し, 術後半年以上の経過においても HNP-1の存在が認め られた。

\section{謝辞}

この稿を終えるに臨み, 本研究の機会を与えて下さり， 御指導と御校閲を賜った岡山大学歯学部口腔外科学第一 講座 菅原利夫教授に束心から感謝いたします。また終始 御想篤なる御指導ならびに御校閲を賜りました岡山大学 歯学部歯科薬理学教室 杉山勝三助教授に深甚なる感謝の 意を表します.さらに本研究を進めるにあたり，終始御援 助, 御助言いただきました口腔外科学第一講座の皆様な らびに, 歯科薬理学教室の皆様に心から感謝いたします.

本論文の要旨は, 第45回 JADR 総会（1997年12月，徳 島）において発表した。

\section{引用 文 献}

1) Mandel, I.D.: The role of saliva in maintaining oral homeostasis. J Am Dent
Assoc 119: 298-304 1989.

2) Hay, D.I.: CRC handbook of experimental aspects of oral biochemistry. CRC press Inc Boca Raton FL: 319-335 1983.

3) 河野正司 : 唾液 歯と口腔の健康. 第 1 版, 医 歯薬出版, 東京 1997,108 頁.

4) James, P.M. and Carl, H.S.: Arachidonic acid metabolites in saliva of patients with squamous cell carcinoma of the head and neck. Oral Surg Oral Med Oral Pathol 77: 636-640 1994.

5) Mizukawa, N., Sugiyama, K., et al.: A peptide detected in the saliva of oralcancer patients. JDR 77: 13091998.

6) Ganz, T., Selsted, M.E., et al.: Defensins: Natural peptide antibiotics of human neutrophiles. $J$ clin Invest 76 : 1427-1435 1985.

7) Eisenhauer, P.B., Harwig, S.S.L., et al.: Cryptdins: antimicrobial defencins of the small intestine. Infect Immun 60: 3556-3565 1992.

8) Lehrer. R.I., Ganz, T., et al.: Defensins: Endogenous Antibiotic Peptides of animal cells. Cell 64: 229-230 1991.

9) 久保木芳徳, 兼平 孝: ヒスタチンの口腔内防 御メカニズム。日本唾液腺学会誌 32: 1-10 1991.

10) Kishimoto, E., Hay, D.I., et al.: A human salivary Protein Which Promotes Adhesion of Streptococcus mutans Serotype c Strains to Hydroxyapatite. Infect Immun 57: 3702-3707 1989.

11）滝尾拡士 : タンパク質 II（新生化学実験講座 1) 日本生化学会編, 第 1 版, 東京化学同人, 東京 1990 , 167頁.

12) UICC: TNM KlassifiKation maligner Tumoren. Vierte Auflage. Springer-Verlag, Berlin, 1987, P 7.

13) Ganz, T., Selsted, M.E., et al.: Defensins. Eur J Haematol 44: 1 - 81990.

14) Selsted, M.E., Tang, Y.-Q., et al: Purification, Primary Structures, and Antibacterial Activities of $\beta$-Defensins, a New Family of Antimicrobial Peptides from Bovine Neutrophils. J Biol Chem 268: 664166481993.

15) Tang, Y.-Q. and Selsted, M.E.: Characterization of the Disulfide Motif in BNBD12 , an Antimicrobial $\beta$-Defensin Peptide from Bovine Neutrophils. J Biol Chem 268: 6649-6653 1993.

16) Schonwetter, B.S., Stolzenberg, E, D., et al.: Epitherial antibiotics induced at sites of inflammation. Science 267: 1645-1648 
1995.

17) Bensch, K.W., Raida, M., et al.: hBD- $1:$ a novel $\beta$-defensin from human plasma. FEBS Lett 368: 331-335 1995.

18) Patterson-Delafield, J., Martineez, R.J., et al.: Microbicidal cationic protein in rabbit alveolar macrophages: a potential host defense mechanism. Infect Immun 30: 180-192 1980.

19) Eisenhauer, P.B., Harwig, S.S.L., et al.: Purification and antimicrobial properties of three defensins from rat neutrophils. Infect Immun 57: 2021-2027 1989.

20) Selsted, M.E. and Harwig, S.S.L.: Purification, primart structure, and antimicrobial activities of a guinea pig neutrophil defensin. Infect Immun 55: 2281-2286 1987.

21) Selsted, M.E. Szklarek, D., et al.: Purification and antibacterial activity of antimicrobial peptides of rabbit granulocytes. Infect Immun 45: 150-154 1984.

22) Ganz, T.: Extracellular release of antimicrobial defensins by human polymorphonuclear leukocytes. Infect Immun 55: 568-571 1987.

23) Jones, D.E. and Bevins, C.L. : Paneth cells of the small human intenstine express an antimicrobial peptide gene. J Biol Chem 267: 23216-23225 1992.

24) Jones, D.E. and Bevins, C.L.: Defensin- 6 mRN A in human Paneth cells: implications for antimicrobial peptides in host defense of the human bowel. FEBS Lett 315: 187-192 1993.

25) Ganz, T., Rayner, J.R., et al.: The structure of the rabbit macrophage defensin genes and their organ-specific expression. J Immunol 143: 1358-1365 1989.

26) Eisenhauer, P.B. and Lehrer, R.I.: Mouse neutrophils lack defensins. Infect Immun 60: 3446-3447 1992.

27) Selsted, M.E., Szklarek, D., et al.: Activity of rabbit leukocyte peptides against Candida albicans. Infect Immun 49: 202 2061985.

28) Borenstein, L.A., Selsted, M.E., et al.: Antimicrovial activity of rabbit leukocyte defensin againt Treponema pallidum subsp. pallidum. Infect Immun 59: 135913671991.

29) Ogata, K., Linzer, B.A.,et al.: Activity defensins from human neutrophilic granu- locyte against Mycobacterium aviumMycobacterium tracellulare. Infect Immun 60: 4720-4725 1992 .

30) Daher, K.E., Selsted, M.E., et al.: Direct inactivation of viruses by human granulocyte defensins. J Virol 60: 1068-1074 1986.

31) Lichtenstein, A.K., Ganz, T., et al.: In vitro tumor cell cytolysis mediated by peptide defensins of human and rabbit granurocyte. Blood 68: 1407-1410 1986.

32) Okrent, D.G., Lichtenstein, A.K., et al.: Direct cytotoxicity of polymorphonuclear leukocyte granule proteins to human lung deri-cells and endothelial cells. Am Rev Respir Dis 141: 179-185 1990.

33) Yamashita, T., Saito, K.: Purification, Primary Structure, and Biological activity of Guinea Pig Neutrophil Cationic Peptides. Infect Immun 57: 2405-2409 1989.

34) Territo, M.C., Ganz, T., et al.: Monocyte chemotactic activity of defensins from human neutrophils. J Clin Invest 84: 2017 20201989.

35) Zhu, Q.Z., Hu, J., et al.: Isolation and structure of corticostatin peptides from rabbit fetal and adult lung. Proc Natl Acad Sci USA 85: 592-596 1988.

36）菊池雅子, 浦 陽子, 他 : 殺菌性物質 Defensins について. 生体防御 10: 113-121 1993.

37) Daher, K.A., Lehrer, R.I., et al.: Isolation and characterization of human defensin cDNA clones. Proc Natl Acad Sci U. S. A. 85: 7327-7331 1988.

38) Valore, E.V. and Ganz, T.: Posttranslational processing of defensins in immature human myeloid cells. Blood 79: 153815441992.

39) Shiomi, K., Nakazato, M., et al.: Establishment of radioimmunoassay for human neutrophil peptides and their increase in plasma and neutrophil in infection. Biochem Biophys Res Commun 195: 13361993.

40) Ashkenazi, M. and Dennison, D.K.: A new method for isolation of salivary neutrophils and determination of their functional activity. J Dent Res 68: 125612611989.

41) Panyutich, A.V., Panyutich, E.A., et al.: Plasma defensin concentrations are elevated in patients with septicemia or bacterial meningitis. J Lab Clin Med 122: 2022071993. 